УДК 004.42:001.895:378.14

DOI:

Олег Маслій, кандидат педагогічних наук, старший науковий співробітник, заступник начальника академії з навчальної роботи, начальник навчального відділу Військової академї, м. Одеса

\title{
АНАЛІЗ ВПЛИВУ ПЕДАГОГІЧНИХ УМОВ СИСТЕМИ ПРОФЕСІЙНОЇ ПІДГОТОВКИ МАЙБУТНІХ ОФІЦЕРІВ РАКЕТНО-АРТИЛЕРІЙСЬКОГО ОЗБРОЄННЯ НА ЯКІСТЬ ЇХНЬОЇ УСПІШНОСТІ
}

У статті розглянуто вплив педагогічних умов системи професійної підготовки майбутніх офіиерів ракетно-артилерійського озброєння на якість їхньої успішності з навчальних дисциплін, задіяних у педагогічному експерименті (“Будова та експлуатація артилерійських приладів”, “Основи побудови ракетноартилерійського озброєння та ремонтних засобів", "Ракети і боєприпаси", “Будова та експлуатаџія ракетно-артилерійського озброєння та електричних систем”, “Організація експлуатації озброєння та військової техніки”) щчодо реалізачії у навчальному процесі вищого військового навчального закладу зазначеноі авторської системи. Наведено зміни, внесені в освітній процес підготовки майбутніх офіцерів ракетноартилерійського озброєння на підставі результатів експериментальної роботи.

Ключові слова: вища освіта;педагогічні умови; професійна підготовка майбутніх офічерів ракетноартилерійського озброєння.

Табл. 4. Літ. 5.

Oleh Masliy, Ph.D.(Pedagogy), Senior Researcher, Deputy of the Head of the Academy of Academic Affairs, Head of the Training Department of the Military Academy, Odesa

\section{THE ANALYSIS OF THE INFLUENCE OF PEDAGOGICAL CONDITIONS OF THE PROFESSIONAL TRAINING SYSTEM OF FUTURE OFFICERS OF MISSILE AND ARTILLERY ARMAMENT ON THE QUALITY OF THEIR PERFORMANCE}

The author offers the system of professional training of future officers of missile and artillery armament as a step towards solving the problem of improving the professional training of future officers of missile and artillery armament taking into account new development and modernization patterns of the Armed Forces of Ukraine. This system includes the enforcement of the following pedagogical conditions: 1) increasing the motivation while developing a willingness for professional work; 2) integration of general and specialized knowledge of professional competence of future officers of missile and artillery armament; 3) developing the skills of combat response of future officers of missile and artillery armament; 4) enhancing the professional competency of the scientific and teaching staff in specific military subjects; as well as developing a willingness of future officers of missile and artillery armament for professional activity.

The article considers the influence of the mentioned pedagogical conditions of the author's system on the quality of cadets' performance in the courses involved in the pedagogical experiment ("Construction and Operation of the Artillery Devices", "Fundamentals of Missile and Artillery Armament and Maintenance Means", "Missiles and Ammunition", "Construction and Operation of Missile and Artillery Armament and Electric System", "Use of Weapons and Military Vehicles") concerning the implementation of the given system into educational process of higher military educational institution.

The analysis, conducted in the article, is indicative of the fact that implementing the author's pedagogical system of professional training of future officers of missile and artillery armament in educational process of military institutions of higher education is effective on the basis of the developed methodology in the context of the mentioned pedagogical conditions.

The article also presents the changes introduced in the educational process of training of future officers of missile and artillery armament on the base of the results of the experimental work.

Keywords: higher education; pedagogical conditions; professional training of future officers of missile and artillery armament.

П остановка проблеми. В сучасній вітчизняній військовій освіті важливою проблемою є розвиток і професійне становлення молодого офіцера. Сьогодні особистість військовослужбовця повинна бути центром уваги, а на передній план виступати формування абсолютно нового ставлення до його професійної підготовки. Тому перед Вищими військовими навчальними закладами України ставиться завдання виховати молоде покоління 


\section{АНАЛІЗ ВПЛИВУ ПЕДАГОГІЧНИХУМОВ СИСТЕМИ ПРОФЕСІЙНОЇ ПІДГОТОВКИ МАЙБУТНІХ ОФІЦЕРІВ РАКЕТНО-АРТИЛЕРІЙСЬКОГО ОЗБРОЄННЯ НА ЯКІСТЬ ЇХНЬОӤ УСПШШНОСТІ}

військових офіцерів, спрямоване на їх особистісний і професійний розвиток.

Одним із шляхів вирішення даного завдання має стати реалізація цільових функцій військової освіти, сучасна тенденція якої передбачає зміну вимог до професійної підготовки майбутніх офіцерів, оцінки ефективності їх виховної та пізнавальної діяльності. Це обумовлює необхідність пошуку нових підходів до взаємодії і відносин між учасниками освітнього процесу, що характеризуються співпрацею, відкритістю, довірою, людською участю і підтримкою $[1 ; 2 ; 5]$.

Аналіз останніх досліджень і публікацій. У наукових пошуках вітчизняні вчені неодноразово звертались до проблематики професійної підготовки військових фахівців. Теоретичний аналіз сучасної військової, психолого-педагогічної літератури (І. Бех, О. Бикова, Д. Блохін, Є. Бондаревська, М. Варій, Л. Доломанюк, М. Єрмошин, Н. Кічук, В. Коровін, Т. Майборода, В. Маслов, М. Нещадим, В. Петрук, О.Савченко, О. Торічний, В. Ягупов та ін.) засвідчив, що сьогодні проблема професійної підготовки військовослужбовців стає все більш актуальною.

Комплексний огляд наукових літературних джерел, поглядів учених щодо методологічних підходів дозволив установити, що в контексті дослідження проблеми професійної підготовки майбутніх офіцерів ракетно-артилерійського озброєння (РАО) увагу системному підходу приділяли такі вчені, як: В. Безпалько, Т. Дмитренко, О. Кудрявцев, Т. Лобанова, Ш. Магомедов, С. Омаров, В. Попов, Т. Суржикова, О. Тутолмін, Е. Юдін та ін.; акмеологічному підходу - С. Бегідова, М. Бендюков, О. Бєлоус, А. Бодальов, Г. Бойченко, Л. Варфоломєєва, Н. Волянюк, А. Деркач, О. Жукова, Е. Зеєр, Г. Ікрін, Н. Костихіна, Н. Кузьміна, Л. Кундозерова, О. Леонтьєв, В. Максимов, В. Петрухін, М. Плугіна, А. Реан, Л. Рибалко, В. Тарасов, С. Толстих, Г. Хазяїнов, С. Хазова та ін.; особистісно орієнтованому підходу М. Акопова, Б. Ананьєв, Л. Виготський, П. Гальперін, В. Давидов, Д. Ельконін, С. Євсєєв, О. Зайчиков, О. Іванова, С. Казанцева, А. Комков, М. Кузнецов, О. Леонтьєв, С. Рубінштейн, Г. Пазекова, Ю. Плотоненко, О. Шолков та ін.

Незважаючи на те, що проблема професійної підготовки майбутніх офіцерів ракетноартилерійського озброєння знаходилася у полі зору західних і вітчизняних вчених, донині не створено цілісної педагогічної концепції, яка б враховувала нові закономірності розвитку і модернізації Збройних Сил України, появу якісно інших вимог $\mathrm{i}$ способів професійної підготовки фахівців військової галузі.
Про недостатність уваги до проблеми професійної підготовки майбутніх офіцерів ракетно-артилерійського озброєння свідчить відсутність науково обгрунтованої професіограми зі спеціальності “141 Електроенергетика, електротехніка та електромеханіка” (спеціалізація - Експлуатація та ремонт ракетного озброєння).

Незважаючи на певну дослідженість проблеми система професійної підготовки майбутніх офіцерів ракетно-артилерійського розроблена недостатньо. Стан професійної підготовки майбутніх офіцерів ракетно-артилерійського озброєння показує, що традиційні форми навчання сьогодні недостатньо сприяють їі ефективному розвитку. Без спеціально організованої системи навчання рівень освіти військовослужбовців низький, що, у свою чергу, суттєво знижує рівень їх загальної професійної підготовки та погіршує обороноздатність держави.

Певним кроком для розв'язання зазначеної проблеми ми пропонуємо систему професійної підготовки майбутніх офіцерів ракетноартилерійського озброєння, яка передбачає реалізацію наступних педагогічних умов: 1) підвищення рівня мотивації в процесі формування готовності до професійної діяльності; 2) інтеграція загальних і спеціальних знань професійної компетенції майбутніх офіцерів ракетно-артилерійського озброєння; 3) формування навичок бойового реагування майбутніх офіцерів ракетно-артилерійського озброєння; 4) підвищення фахової компетентності науково-педагогічних працівників дисциплін військово-професійної підготовки, та спрямована на формування готовності майбутніх офіцерів ракетноартилерійського озброєння до професійної діяльності [2; 3].

Мета і завдання статті. Проаналізувати вплив педагогічних умов системи професійної підготовки майбутніх офіцерів ракетноартилерійського озброєння на якість їхньої успішності після проведення експерименту щодо реалізації у навчальному процесі ВВНЗ зазначеної авторської системи.

Виклад основного матеріалу дослідження. Впровадивши педагогічну систему професійної підготовки майбутніх офіцерів ракетноартилерійського озброєння в освітній процес ВВНЗ ми отримали та проаналізували результати сформованості готовності майбутніх офіцерів РАО до професійної діяльності. Далі доречно провести аналіз впливу кожної з чотирьох визначених педагогічних умов на результати успішності курсантів $з$ навчальних дисциплін, задіяних у педагогічному експерименті (“Будова та 


\section{АНАЛІЗ ВПЛИВУ ПЕДАГОГІЧНИХУМОВ СИСТЕМИПРОФЕСІЙНОӤ ПІДГОТОВКИМАЙБУТНІХ ОФІЕРІВ РАКЕТНО-АРТИЛЕРІЙСЬКОГО ОЗБРОСННЯ НАЯКІСТЬ ЇХНЬОӤ УСПІШНОСТІ}

експлуатація артилерійських приладів”, “Основи побудови ракетно-артилерійського озброєння та ремонтних засобів", “Ракети і боєприпаси”, "Будова та експлуатація ракетно-артилерійського озброєння та електричних систем”, “Організація експлуатації озброєння та військової техніки”), та тим самим підтвердити доцільність їхнього включення в авторську педагогічну систему професійної підготовки майбутніх офіцерів РАО.

Результати застосування першої педагогічної умови - підвищення рівня мотиващії в процесі формування готовності до професійной діяльності, представлено в таблиці 1.
4,09 і 4,21 відповідно); за показниками якості знань кількість майбутніх офіцерів РАО, які навчались на "4" i “5” в експериментальній групі збільшилась на $11,25 \%$, а в контрольній - на 4,05\%. Це $\epsilon$ вагомою підставою стверджувати про дієвість першої педагогічної умови: у ЕГ спостерігається зростання показників середнього і високого рівнів, а також зменшення показника низького рівня сформованості готовності майбутніх офіцерів РАО до професійної діяльності. Зміни показників рівнів сформованості готовності майбутніх офіцерів РАО до професійної діяльності в контрольних групах були незначними.

Таблиця 1.

Успішність майбутніх офіцерів РАО внаслідок упровадження першої педагогічної умови

\begin{tabular}{|c|c|c|c|c|c|c|c|c|c|c|c|}
\hline \multirow{3}{*}{$\begin{array}{c}\text { Гупи } \\
(\mathrm{K})\end{array}$} & \multirow[t]{3}{*}{ EK } & \multicolumn{6}{|c|}{ Успішність майбутніх офіцерів РАО } & \multirow[t]{3}{*}{ СБ } & \multirow[t]{3}{*}{ ПСБ } & \multirow{3}{*}{$\begin{array}{c}\text { Я3, } \\
\%\end{array}$} & \multirow[t]{3}{*}{ ПЯЗ } \\
\hline & & \multicolumn{2}{|c|}{$\begin{array}{c}\text { Низький } \\
\text { рівень, “3” }\end{array}$} & \multicolumn{2}{|c|}{$\begin{array}{c}\text { Середній } \\
\text { рівень, “4” }\end{array}$} & \multicolumn{2}{|c|}{$\begin{array}{c}\text { Високий } \\
\text { рівень, “5” }\end{array}$} & & & & \\
\hline & & K & $\%$ & K & $\%$ & K & $\%$ & & & & \\
\hline \multirow{2}{*}{$\begin{array}{c}\mathrm{K} \Gamma \\
(224)\end{array}$} & $\mathrm{BK}$ & 61 & 27,45 & 126 & 56,7 & 37 & 16,65 & 3,89 & \multirow[t]{2}{*}{0,01} & 72,7 & \multirow[t]{2}{*}{$-0,4$} \\
\hline & ПК & 62 & 27,9 & 121 & 54,45 & 41 & 18,45 & 3,99 & & 72,3 & \\
\hline \multirow{2}{*}{$\begin{array}{c}\mathrm{E} \Gamma \\
(224)\end{array}$} & $\mathrm{BK}$ & 39 & 16,2 & 133 & 59,85 & 52 & 23,4 & 4,09 & \multirow[t]{2}{*}{0,12} & 82,5 & \multirow[t]{2}{*}{11,2} \\
\hline & ПК & 14 & 6,3 & 147 & 66,15 & 63 & 28,35 & 4,21 & & 93,7 & \\
\hline
\end{tabular}

Умовні позначення до таблиці:

КГ - контрольна група; ЕГ - експериментальна група; ЕК - етапи контролю; ВК - вхідний контроль;

ПК - підсумковий контроль; К - кількість курсантів; СБ - середній бал; ПСБ -приріст середнього балу;

ЯЗ - якість знань; ПЯЗ - приріст якості знань.

Аналіз результатів успішності майбутніх офіцерів РАО (за результатами аналізу вхідного та підсумкового контролю знань) дає підстави зробити висновок, що застосування в освітньому процесі ВЗВО першої педагогічної умови сприяє формуванню готовності курсантів до професійної діяльності. За показниками підсумкового контролю, приріст середнього балу в експериментальній групі становив 0,12 бала (середній бал 3,89 і 3,99), тоді як у контрольній групі - 0,10 бала (середній бал
Проаналізуємо отримані результати успішності курсантів внаслідок впровадження другої педагогічної умови - інтеграція загальних $i$ спеціальних знань професійної компетенції майбутніх офіцерів ракетно-артилерійського озброєння (табл. 2).

Представлені в таблиці 2 дані дають підстави зробити висновок про позитивний вплив другої педагогічної умови на сформованість готовності майбутніх офіцерів РАО до професійної діяльності,

Таблиця 2.

Успішність майбутніх офіцерів РАО внаслідок упровадження другої педагогічної умови

\begin{tabular}{|c|c|c|c|c|c|c|c|c|c|c|c|}
\hline \multirow{3}{*}{$\begin{array}{c}\text { Гупи } \\
(\mathrm{K})\end{array}$} & \multirow[t]{3}{*}{ EK } & \multicolumn{6}{|c|}{ Успішність майбутніх офіцерів РАО } & \multirow[t]{3}{*}{ СБ } & \multirow[t]{3}{*}{ ПСБ } & \multirow{3}{*}{$\begin{array}{c}\text { Я3, } \\
\%\end{array}$} & \multirow[t]{3}{*}{ ПЯЗ } \\
\hline & & \multicolumn{2}{|c|}{$\begin{array}{c}\text { Низький } \\
\text { рівень, “3”" }\end{array}$} & \multicolumn{2}{|c|}{$\begin{array}{c}\text { Середній } \\
\text { рівень, “4”" }\end{array}$} & \multicolumn{2}{|c|}{$\begin{array}{c}\text { Високий } \\
\text { рівень, "5" }\end{array}$} & & & & \\
\hline & & K & $\%$ & K & $\%$ & K & $\%$ & & & & \\
\hline \multirow{2}{*}{$\begin{array}{c}\text { КГ } \\
\text { (224) }\end{array}$} & $\mathrm{BK}$ & 64 & 28,8 & 131 & 58,95 & 29 & 13,05 & 3,84 & \multirow[t]{2}{*}{0,06} & 71,4 & \multirow[t]{2}{*}{2,2} \\
\hline & ПК & 59 & 26,55 & 127 & 57,15 & 38 & 17,1 & 3,9 & & 73,6 & \\
\hline \multirow{2}{*}{$\begin{array}{c}\mathrm{E} \Gamma \\
(224)\end{array}$} & $\mathrm{BK}$ & 33 & 14,85 & 134 & 60,3 & 57 & 25,65 & 4,1 & \multirow[t]{2}{*}{0,15} & 85,2 & \multirow[t]{2}{*}{7,2} \\
\hline & ПК & 17 & 7,65 & 133 & 64,35 & 74 & 28,8 & 4,25 & & 92,4 & \\
\hline
\end{tabular}




\section{АНАЛІЗ ВПЛИВУ ПЕДАГОГІЧНИХУМОВ СИСТЕМИПРОФЕСІЙНОӤ ПІДГОТОВКИ МАЙБУТНІХ ОФІЦЕРІВ РАКЕТНО-АРТИЛЕРІЙСЬКОГО ОЗБРОЄННЯ НА ЯКІСТЬ ЇХНЬОӤ УСПШШНОСТІ}

зокрема: приріст середнього балу в експериментальній групі становив 0,15 бала, а в контрольній групі тільки 0,06 бала; за показниками якості знань кількість майбутніх офіцерів РАО середнього і високого рівнів в експериментальній групі зросла на 7,2 \%, а в контрольній - на 2,2 \% відповідно. Тобто, в експериментальній групі спостерігається зростання показника середнього і високого рівнів, у той час як показники низького рівня зменшуються. В контрольній групі відбувається незначна зміна показників рівнів сформованості готовності майбутніх офіцерів РАО до професійної діяльності, що, вважаємо, є результатом організації традиційного освітнього процесу.

Розглянемо результати, отримані внаслідок впровадження третьої педагогічної умови формування навичок бойового реагування майбутніх офіиеерів ракетно-артилерійського озброєння (табл. 3 ).

Дані таблиці 3 засвідчують позитивний вплив третьої педагогічної умови на сформованість готовності майбутніх офіцерів РАО до професійної діяльності, зокрема: приріст середнього балу в експериментальній групі становив 0,12 бала, а в контрольній групі тільки 0,03 бала; за показниками якості знань кількість майбутніх офіцерів РАО середнього і високого рівнів в експериментальній групі зросла на 10,3 \%, а в контрольній - на 8,5 \% відповідно. Отже, в експериментальній групі спостерігається зростання показника середнього (на 7,2 \%) і високого рівнів (на $3,15 \%$ ), у той час як показники низького рівня зменшуються на $10,35 \%$. У контрольній групі відбувається незначна зміна показників рівнів сформованості готовності майбутніх офіцерів РАО до професійної діяльності, що ми, знов таки, повјязуємо 3 наслідками традиційної організації освітнього процесу.

Результати отримані внаслідок реалізації четвертої педагогічної умови - підвищення фахової компетентності науково-педагогічних працівників дисииплін військово-професійноі підготовки представлені в таблиці 4.

Аналіз даних таблиці 4 дає підстави зробити

Таблиця 3.

Успішність майбутніх офіцерів РАО внаслідок упровадження третьої педагогічної умови

\begin{tabular}{|c|c|c|c|c|c|c|c|c|c|c|c|}
\hline \multirow{3}{*}{$\begin{array}{c}\text { Гупи } \\
(\text { К) }\end{array}$} & \multirow[t]{3}{*}{ EK } & \multicolumn{6}{|c|}{ Успішність майбутніх офіцерів РАО } & \multirow[t]{3}{*}{ СБ } & \multirow[t]{3}{*}{ ПСБ } & \multirow{3}{*}{$\begin{array}{c}\text { Я3, } \\
\%\end{array}$} & \multirow[t]{3}{*}{ ПЯЗ } \\
\hline & & \multicolumn{2}{|c|}{$\begin{array}{c}\text { Низький } \\
\text { рівень, “3““ }\end{array}$} & \multicolumn{2}{|c|}{$\begin{array}{c}\text { Середній } \\
\text { рівень, “4”" }\end{array}$} & \multicolumn{2}{|c|}{$\begin{array}{c}\text { Високий } \\
\text { рівень, “5” }\end{array}$} & & & & \\
\hline & & K & $\%$ & K & $\%$ & K & $\%$ & & & & \\
\hline \multirow{2}{*}{$\begin{array}{c}\text { КГ } \\
(224)\end{array}$} & BK & 66 & 29,7 & 137 & 61,65 & 21 & 9,45 & 3,79 & \multirow[t]{2}{*}{0,03} & 70,5 & \multirow[t]{2}{*}{8,5} \\
\hline & ПК & 41 & 18,45 & 149 & 67,05 & 28 & 12,6 & 3,82 & & 79,0 & \\
\hline \multirow{2}{*}{$\begin{array}{c}\mathrm{E} \Gamma \\
(224)\end{array}$} & BK & 54 & 24,3 & 141 & 63,45 & 29 & 13,05 & 3,88 & \multirow[t]{2}{*}{0,12} & 75,8 & \multirow[t]{2}{*}{10,3} \\
\hline & ПК & 31 & 13,95 & 157 & 70,65 & 36 & 16,2 & 407 & & & \\
\hline
\end{tabular}

Умовні позначення до таблиці:

КГ - контрольна група; ЕГ - експериментальна група; ЕК - етапи контролю; ВК - вхідний контроль; ПК - підсумковий контроль; К - кількість курсантів; СБ - середній бал; ПСБ -приріст середнього балу; ЯЗ - якість знань; ПЯЗ - приріст якості знань.

Таблиця 4.

Успішність майбутніх офіцерів РАО внаслідок упровадження четвертої педагогічної умови

\begin{tabular}{|c|c|c|c|c|c|c|c|c|c|c|c|}
\hline \multirow{3}{*}{$\begin{array}{c}\text { Гупи } \\
(\mathrm{K})\end{array}$} & \multirow[t]{3}{*}{ EK } & \multicolumn{6}{|c|}{ Успішність майбутніх офіцерів РАО } & \multirow[t]{3}{*}{ СБ } & \multirow[t]{3}{*}{ ПСБ } & \multirow{3}{*}{$\begin{array}{c}\text { Я3, } \\
\%\end{array}$} & \multirow[t]{3}{*}{ ПЯЗ } \\
\hline & & \multicolumn{2}{|c|}{$\begin{array}{l}\text { Низький } \\
\text { рівень, “3““ }\end{array}$} & \multicolumn{2}{|c|}{$\begin{array}{c}\text { Середній } \\
\text { рівень, “4”" }\end{array}$} & \multicolumn{2}{|c|}{$\begin{array}{c}\text { Високий } \\
\text { рівень, “5” }\end{array}$} & & & & \\
\hline & & K & $\%$ & K & $\%$ & K & $\%$ & & & & \\
\hline \multirow{2}{*}{$\begin{array}{c}\text { КГ } \\
(224)\end{array}$} & BK & 69 & 31,05 & 129 & 58,05 & 26 & 11,7 & 3,8 & \multirow[t]{2}{*}{0,1} & 69,1 & \multirow[t]{2}{*}{3,6} \\
\hline & ПК & 61 & 27,45 & 124 & 55,8 & 39 & 17,55 & 3,9 & & 72,7 & \\
\hline \multirow{2}{*}{$\begin{array}{c}\mathrm{E} \Gamma \\
(224)\end{array}$} & $\mathrm{BK}$ & 39 & 17,55 & 133 & 59,89 & 52 & 23,4 & 4,05 & \multirow[t]{2}{*}{0,2} & 82,5 & \multirow[t]{2}{*}{10,08} \\
\hline & ПК & 15 & 6,75 & 136 & 61,2 & 73 & 32,85 & 4,25 & & 93,3 & \\
\hline
\end{tabular}

Умовні позначення до таблиці:

КГ - контрольна група; ЕГ - експериментальна група; ЕК - етапи контролю; ВК - вхідний контроль; ПК - підсумковий контроль; К - кількість курсантів; СБ - середній бал; ПСБ -приріст середнього балу; ЯЗ - якість знань; ПЯЗ - приріст якості знань. 


\section{АНАЛІЗ ВПЛИВУ ПЕДАГОГІЧНИХУМОВ СИСТЕМИ ПРОФЕСЙНОӤ ПІДГОТОВКИ МАЙБУТНІХ}

ОФІЦЕРІВ РАКЕТНО-АРТИЛЕРІЙСЬКОГО ОЗБРОЄННЯ НА ЯКІСТЬ ЇХНЬОЇ УСПШШНОСТІ

висновок про позитивний вплив четвертої педагогічної умови на сформованість готовності майбутніх офіцерів РАО до професійної діяльності, зокрема: приріст середнього балу в експериментальній групі становив 0,2 бала, а в контрольній групі - 0,1 бала; за показниками якості знань кількість майбутніх офіцерів РАО середнього і високого рівнів в експериментальній групі зросла на 10,08 \%, а в контрольній - на 3,6 \% відповідно. В експериментальній групі спостерігається зростання показника середнього (на 3,0 \%) і високого рівнів (на 9,45 \%), у той час як показники низького рівня зменшуються на 10,8 \%. У контрольній групі відбувається незначна зміна показників рівнів сформованості готовності майбутніх офіцерів РАО до професійної діяльності, що $\epsilon$ результатом природного розвитку особистості науково-педагогічного працівника у навчально-виховному середовищі ВВНЗ.

Висновки. Аналіз результатів успішності курсантів 3 навчальних дисциплін, задіяних у педагогічному експерименті (“Будова та експлуатація артилерійських приладів”, “Основи побудови ракетно-артилерійського озброєння та ремонтних засобів", "Ракети і боєприпаси”, “Будова та експлуатація ракетно-артилерійського озброєння та електричних систем”, “Організація експлуатації озброєння та військової техніки”), дав підстави для висновку, що застосування в освітньому процесі військових закладів вищої освіти авторської педагогічної системи професійної підготовки майбутніх офіцерів ракетно-артилерійського озброєння є ефективним за розробленою методикою в контексті задіяних педагогічних умов.

У результаті проведеного педагогічного експерименту проведено низкузмін в освітній процес підготовки майбутніх офіцерів РАО, зокрема:

- у навчальні плани і робочі програми дисциплін вносилися зміни, які найбільш повно відображають відповідність кваліфікаційних вимог до рівня підготовки випускників ВЗВО;

- у зміст навчальних дисциплін професійної підготовки вводили навчальний матеріал, що відображає сучасний рівень розвитку військової науки, техніки, ракетно-артилерійського озброєння, особливості застосування ЗС України у військових конфліктах;

- в практику проведення всіх видів занять включали практичні, ситуативні та нестандартні задачі за посадовим призначенням;

- для вироблення у курсантів навичок ухвалення рішень щодо ведення професійної діяльності стали застосовувати комп'ютерне моделювання;

- широку практику в процесі підготовки курсантів отримало проведення тренувань 1 практик навчально-бойового чергування на навчально-командному пункті;

- більшість науково-педагогічних працівників стали широко використовувати методи інтерактивного навчання, елементи інноваційних педагогічних технологій тощо.

За підсумками проведеного експериментального дослідження вдалося домогтися у більшості курсантів ЕГ розуміння та оволодіння змістом таких понять і категорій, як "професійна готовність”, “професійна компетентність”; сформувати вміння і навички: самостійно набувати й акумулювати нові знання з різних джерел, використовувати набуті знання, вміння та навички для подальшого самовдосконалення, вміло застосовувати їх під час виконання посадових обов'язків у військах.

Зазначимо, що розроблена педагогічна система професійної підготовки майбутніх офіцерів ракетно-артилерійського озброєння є дієвим засобом підтримки високого рівня ефективності освітнього процесу. Під час експериментальної роботи сформульовано основні логіко-взаємопов'язані кроки, реалізація яких дозволила підвищити ефективність професійної підготовки майбутніх офіцерів ракетноартилерійського озброєння, а саме:

- оптимізація організаційної структури та змісту вивчення навчальних дисциплін професійної підготовки;

- впровадження сучасних технологій (IKT, дистанційні, інтерактивні) у процес формування готовності майбутніх офіцерів РАО до професійної діяльності;

- активізація самовдосконалення курсантів із розвитку професійної компетентності.

\section{ЛІТЕРАТУРА}

1. Концепція підготовки Збройних Сил України. URL: https://www.ukrmilitary.com/2016/02/conceptof-the-armed-forces-of-ukraine.html. (дата звернення: 10.08.2018 p.).

2. Концепція розвитку сектору безпеки i оборони України / затв. Указом Президента України "Про рішення Ради національної безпеки і оборони України від 4 березня 2016 року “Про Концепцію розвитку сектору безпеки і оборони України”: від 14.03.2016 р., № 92/2016 // Офіційний вісник Президента України. 2016. № 10. С. 195.

3. Маслій О. Методологічні засади організації підготовки до майбутньої професійної діяльності офіцерів служби РАО. Збірник наукових праць НАДПСУ. Хмельницький, 2019. Серія: Педагогічні науки. №1(16). С. 279-298. 
4. Маслій О. Педагогічна система професійної підготовки майбутніх офіцерів ракетноартилерійського озброєння. Збірник наукових праць Уманського державного педагогічного університету. Умань, 2019. Випуск 1. С. 83-90.

5. Маслій О. Сучасні тенденції у професійній підготовці майбутніх офіцерів ракетноартилерійського озброєння. Імперативи розвитку громадянського суспільства у забезпеченні національної конкурентоспроможності: матеріали I міжнародної науково-практичної конференції (Батумі, 13-14 грудня 2018 р.). Батумі, 2018. C. 246-248.

\section{REFERENCES}

1. Kontseptsiia pidhotovky Zbroinykh Syl Ukrainy [Concept of training of the Armed Forces of Ukraine]. Available at: https://www.ukrmilitary.com/2016/02/ concept-of-the-armed-forces-of-ukraine.html. (accessed 10 Aug. 2018 ). [in Ukrainian].

2. Kontseptsiia rozvytku sektoru bezpeky i oborony Ukrainy / zatv. Ukazom Prezydenta Ukrainy Pro rishennia Rady natsionalnoi bezpeky i oborony Ukrainy vid 4 bereznia 2016 roku Pro Kontseptsiiu rozvytku sektoru bezpeky i oborony Ukrainy: vid 14.03.2016 r., № 92/2016 [Concept of development of the security and defense sector of Ukraine / approved. Presidential Decree "On the Decision of the National Security and Defense Council of Ukraine of March 4, 2016“ On the Concept of Development of the Security and Defense Sector of Ukraine": dated 14 March 2016]. Official Bulletin of the President of Ukraine. 2016. No. 10. p. 195. [in Ukrainian].

3. Maslii, O. (2019). Metodolohichni zasady orhanizatsii pidhotovky do maibutnoi profesiinoi diialnosti ofitseriv sluzhby RAO [Methodological principles of organization of preparation for future professional activity of RAO officers]. Collection of scientific works of NADPSU. Khmelnitsky, 2019. Series: Pedagogical Sciences. No.1(16). pp. 279-298. [in Ukrainian].

4. Maslii, O. (2019). Pedahohichna systema profesiinoi pidhotovky maibutnikh ofitseriv raketnoartyleriiskoho ozbroiennia [Pedagogical system of professional training of future missile and artillery officers]. Collection of scientific works of Uman State Pedagogical University. Vol. 1. pp. 83-90. [in Ukrainian].

5. Maslii, O. (2018). Suchasni tendentsii u profesiinii pidhotovtsi maibutnikh ofitseriv raketnoartyleriiskoho ozbroiennia [Current trends in the training of future missile and artillery officers]. Imperatyvy rozvytku hromadianskoho suspilstva $u$ zabezpechenni natsionalnoi konkurentospromozhnosti: materialy I mizhnarodnoi naukovo-praktychnoi konferentsii (Batumi, 13-14 hrudnia 2018 r.). Civil society development imperatives in ensuring national competitiveness: Proceedings of the $1 \mathrm{st}$ International Scientific and Practical Conference (Batumi, December 13-14, 2018). Batumi, pp. 246248. [in Ukrainian].

Стаття надійшла до редакції 02.10.2019

\title{
G58080

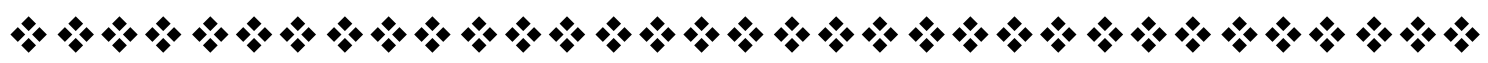

“Точне логічне визначення понять - умова істинного знання".

$$
\text { давньогрецький ббілособ }
$$

“Заняття науқою живлять юність $i$ приносять насолоду старості, приқрашають в щасті, служать притулқом і розрадою в нещасті”.

Iुиерон давнъоримський політичний діяч, видатний оратор, ббілособ та літератор

“Освіта повинна бути істинною, повною, ясною $і$ міцною”.

\author{
Унсур Аль-Маалі (Кей Кабус) \\ персидський письменник
}

\section{G580801205

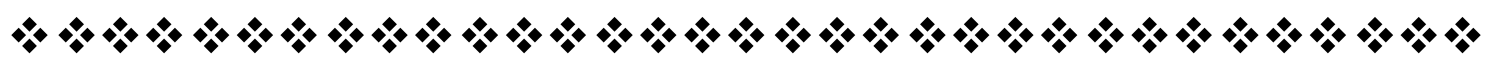

